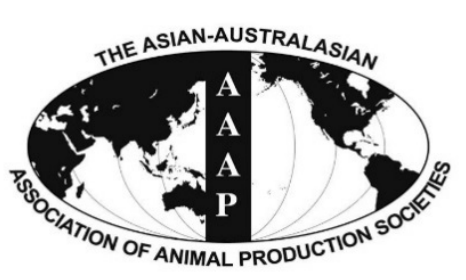

\begin{tabular}{c} 
Open Access \\
$\begin{array}{c}\text { Asian Australas. J. Anim. Sci. } \\
\text { Vol. 29, No. } 7: \mathbf{9 9 8 - 1 0 0 3 ~ J u l y ~} 2016 \\
\text { http://dx.doi.org/10.5713/ajas.15.0886 }\end{array}$ \\
\hline www.ajas.info \\
\hline pISSN 1011-2367 elSSN 1976-5517
\end{tabular}

\title{
Performance Responses, Nutrient Digestibility, Blood Characteristics, and Measures of Gastrointestinal Health in Weanling Pigs Fed Protease Enzyme
}

\author{
Glenmer B. Tactacan ${ }^{1}$, Seung-Yeol Cho ${ }^{2}$, Jin H. Cho ${ }^{3}$, and In H. Kim* \\ Department of Animal Resources and Science, Dankook University, Cheonan 330-714, Korea
}

\begin{abstract}
Although exogenous protease enzymes have been used in poultry diets quite extensively, this has not been the case for pig diets. In general, due to their better gut fermentative capacity and longer transit time, pigs have greater capacity to digest dietary proteins than poultry. However, in early-weaned piglets, the stress brought about by weaning adversely affects the digestion of dietary proteins. Therefore, a study was conducted to determine the effects of a commercial protease enzyme in weanling pigs. Indices of growth, nutrient digestibility, blood profiles, fecal microflora, fecal gas emission and fecal scores were measured during the study. A total of 50 weanling pigs $(6.42 \pm 0.12 \mathrm{~kg}$ ) at $28 \mathrm{~d}$ of age were randomly assigned to receive 1 of 2 dietary treatments: i) control diet (corn-soy based) with no supplemental protease (CON), and ii) control diet $+200 \mathrm{~g} /$ ton protease (PROT) for $42 \mathrm{~d}$. A completely randomized design consisting of 2 treatments, 5 replicates, and 5 pigs in each replicate was used. Growth performance in terms of body weight $(27.04 \pm 0.38 \mathrm{~kg}$ vs $25.75 \pm 0.39 \mathrm{~kg} ; \mathrm{p}<0.05)$ and average daily gain $(491 \pm 7.40 \mathrm{~g}$ vs $460 \pm 7.46 \mathrm{~g} ; \mathrm{p}<0.05)$ in PROT fed pigs were increased significantly, but gain per feed $(0.700 \pm 0.01$ vs $0.678 \pm 0.01 ; \mathrm{p}>0.05)$ was similar between treatments at $\mathrm{d} 42$. Relative to CON pigs, PROT fed pigs had increased $(\mathrm{p}<0.05)$ apparent total tract digestibility $(84.66 \% \pm 0.65 \%$ vs $81.21 \% \pm 1.13 \%$ dry matter and $84.02 \% \pm 0.52 \%$ vs $80.47 \% \pm 1.22 \%$ nitrogen) and decreased $(\mathrm{p}<0.05) \mathrm{NH}_{3}$ emission $(2.0 \pm 0.16 \mathrm{ppm}$ vs $1.2 \pm 0.12 \mathrm{ppm})$ in the feces at $\mathrm{d} 42$. Except for a decreased $(\mathrm{p}<0.05)$ in blood creatinine level, no differences were observed in red blood cell, white blood cell, lymphocyte, urea nitrogen, and IgG concentrations between treatments. Fecal score and fecal microflora (Lactobacillus and E. coli) were also similar between CON and PROT groups. Overall, the supplementation of protease enzyme in weanling pigs resulted in improved growth rate and nutrient digestibility. Exogenous protease enzyme reduced fecal $\mathrm{NH}_{3}$ emission, thus, potentially serving as a tool in lowering noxious gas contribution of livestock production in the environment. (Key Words: Enzyme, Growth Performance, Nutrient Digestibility, Protease, Weanling Pig)
\end{abstract}

\section{INTRODUCTION}

Weaning is a critical period in the pig rearing process. At this time, the piglets are exposed to different types of stressors (environmental, nutritional, psychological, and social), causing physiological changes in the structure and function of the piglet's digestive tract. Pluske et al. (1997) and Boudry et al. (2004) reported the shortening of the villi

\footnotetext{
* Corresponding Author: In H. Kim. Tel: +82-41-550-3652, Fax: +82-41-553-1618, E-mail: inhokim@dankook.ac.kr

${ }^{1}$ JEFO Innovation and Development, JEFO Nutrition Inc., SaintHyacinthe, Quebec, J2S 7B6, Canada.

${ }^{2}$ Eugenebio, Suwon 443-380, Korea.

${ }^{3}$ Department of Animal Science, Chungbuk National University, Cheongju 361-763, Korea.

Submitted Oct. 27, 2015; Revised Jan. 7, 2016; Accepted Mar. 16, 2016
}

and the elongation of the crypt depth immediately after weaning. On the other hand, Hedemann and Jensen (2004) reported a significant reduction in the activity of pancreatic trypsin and chymotrypsin in newly weaned pigs. As a result, the digestive and absorptive capacity of the piglet is impaired, leading to poor performance such as slow growth rate, poor feed conversion, and high incidence of diarrhea.

The diets for weanling pig usually contain high levels of protein to promote early growth and muscle deposition. Therefore, coupled with piglet's poor capacity to digest and absorb dietary nutrients like proteins, high levels of undigested protein may accumulate and promote microbial fermentation and proliferation of pathogenic bacteria in the gastrointestinal tract. Microbial fermentation of undigested protein produces toxic substances such as ammonia and amines (Htoo et al., 2007), both of which can reduce growth 
(Gaskins, 2000) and cause diarrhea in piglets (Porter and Kentworthy, 1969, Dong et al., 1996). In addition, increased ammonia excretion in piggery farms poses a major environmental problem.

Recently, interests on the use of exogenous protease enzyme to improve protein utilization in livestock animals led to the conduct of studies related to this field (Yu et al., 2006; Wang et al., 2011; Guggenbuhl et al., 2012; Adebiyi and Olukosi, 2015; Opoku et al., 2015). However, to date, most of the available information on the application of protease enzyme has been generated from poultry studies with limited studies being done in pigs. Given the need for a nutritional tool to support piglets in processing dietary proteins at the time of weaning, the current study was conducted to determine the effects of exogenous protease enzyme on growth performance, nutrient digestibility, blood characteristics, and measures of gastrointestinal health in weanling pigs.

\section{MATERIALS AND METHODS}

The experimental protocol describing the management and care of animals were reviewed and approved by the Animal Care and Use Committee of Dankook University. The protease enzyme was provided by JEFO Nutrition Inc. of Saint-Hyacinthe, QC, Canada. The enzyme is an alkaline serine endopeptidase produced from bacterial fermentation product with an optimal $\mathrm{pH}$ of 8.5 .

\section{Experimental design, animals, and housing}

A total of 50 weanling pigs ([Yorkshire $\times$ Landrace] $\times$ Duroc) with an average body weight (BW) of $6.42 \pm 0.12 \mathrm{~kg}$ (28 d of age) were used in a 42-d experiment. Pigs were randomly allotted to 2 experimental diets according to their initial BW. There were 5 replicate pens per treatment with 5 pigs per pen. The dietary treatment groups were i) control $(\mathrm{CON})$, basal diet; and ii) basal diet $+0.02 \%$ exogenous protease enzyme (PROT). All nutrients in diets were formulated to meet or exceed the recommendation of NRC (2012) for weanling pigs and fed in a crumble form (Table 1). All the pigs were housed in an environmentally controlled room with a slatted plastic floor. Each pen was equipped with a 1-sided, stainless steel self-feeder and a nipple drinker to allow the pig ad libitum access to feed and water throughout the experimental period.

\section{Sampling and measurements}

Individual pig BW and feed consumption on a per pen basis were recorded on $\mathrm{d} 1,7,21$, and 42 to calculate average daily gain (ADG), average daily feed intake (ADFI), and gain per feed (G/F). Apparent total tract digestibility (ATTD) of dry matter (DM), gross energy (GE), and nitrogen (N) was determined using chromic oxide $(0.2 \%)$ as an inert indicator
Table 1. Composition of experimental diets, as-fed basis

\begin{tabular}{|c|c|c|c|}
\hline Items & D 1 to 7 & D 8 to 21 & D 22 to 42 \\
\hline \multicolumn{4}{|l|}{ Ingredients (\%) } \\
\hline Extruded corn & 29.18 & 44.49 & 61.97 \\
\hline $\begin{array}{l}\text { Dehulled soybean meal } \\
(48 \% \mathrm{CP})\end{array}$ & 6.94 & 16.20 & 25.30 \\
\hline $\begin{array}{l}\text { Fermented soybean meal } \\
(45 \% \mathrm{CP})\end{array}$ & 10.00 & 5.00 & 2.50 \\
\hline Fish meal $(66 \% \mathrm{CP})$ & 5.00 & 3.50 & - \\
\hline Soy oil & 3.65 & 2.55 & 1.05 \\
\hline Lactose & 15.30 & 8.30 & - \\
\hline Whey & 15.00 & 10.00 & 5.00 \\
\hline Monocalcium phosphate & 1.45 & - & - \\
\hline Dicalcium phosphate & - & 1.50 & - \\
\hline Sugar & 5.00 & 3.00 & - \\
\hline Plasma powder & 6.00 & 3.00 & - \\
\hline L-lysine-HCl, 78\% & 0.29 & 0.39 & 0.46 \\
\hline DL-methionine, $50 \%$ & 0.32 & 0.30 & 0.24 \\
\hline L-threonine, $89 \%$ & 0.13 & 0.19 & 0.20 \\
\hline Choline chloride, $25 \%$ & 0.20 & 0.10 & 0.10 \\
\hline Vitamin premix $^{1}$ & 0.10 & 0.10 & 0.10 \\
\hline Trace mineral premix ${ }^{2}$ & 0.20 & 0.20 & 0.20 \\
\hline Limestone & 1.24 & 0.98 & 1.13 \\
\hline Salt & - & 0.20 & 0.25 \\
\hline Total & 100.00 & 100.00 & 100.00 \\
\hline \multicolumn{4}{|l|}{ Calculated composition } \\
\hline $\mathrm{ME}(\mathrm{kcal} / \mathrm{kg})$ & 3,640 & 3,540 & 3,410 \\
\hline \multicolumn{4}{|l|}{ Analyzed composition (\%) } \\
\hline Crude protein & 21.12 & 19.87 & 19.07 \\
\hline Lysine & 1.65 & 1.53 & 1.32 \\
\hline Methionine & 0.61 & 0.60 & 0.55 \\
\hline Calcium & 0.97 & 0.91 & 0.87 \\
\hline Phosphorus & 0.82 & 0.73 & 0.67 \\
\hline Crude fiber & 1.39 & 1.79 & 2.49 \\
\hline
\end{tabular}

${ }^{1}$ Provided per kg of complete diet: 11,025 IU of vitamin A, 1,103 IU of vitamin $\mathrm{D}_{3}, 44 \mathrm{IU}$ of vitamin $\mathrm{E}, 4.4 \mathrm{mg}$ of vitamin $\mathrm{K}, 8.3 \mathrm{mg}$ of riboflavin, $50 \mathrm{mg}$ of niacin, $4 \mathrm{mg}$ of thiamine, $29 \mathrm{mg}$ of d-pantothenic, $60 \mathrm{mg}$ of biotin, $166 \mathrm{mg}$ of choline, and $33 \mu \mathrm{g}$ of vitamin $\mathrm{B}_{12}$.

${ }^{2}$ Provided per kg of complete diet: $80 \mathrm{mg}$ of $\mathrm{Fe}\left(\mathrm{as} \mathrm{FeSO}_{4} 7 \mathrm{H}_{2} \mathrm{O}\right), 12 \mathrm{mg}$ of $\mathrm{Cu}$ (as $\mathrm{CuSO}_{4} \cdot 5 \mathrm{H}_{2} \mathrm{O}$ ), $85 \mathrm{mg}$ of $\mathrm{Zn}\left(\right.$ as $\mathrm{ZnSO}_{4}$ ), $8 \mathrm{mg}$ of $\mathrm{Mn}$ (as $\mathrm{MnO}_{2}$ ), $0.28 \mathrm{mg}$ of I (as KI), and $0.15 \mathrm{mg}$ of $\mathrm{Se}\left(\right.$ as $\left.\mathrm{Na}_{2} \mathrm{SeO}_{3} \cdot 5 \mathrm{H}_{2} \mathrm{O}\right)$.

(Kong and Adeola, 2014). Pigs were fed diets mixed with chromic oxide from d 14 to 21 and from d 35 to 42 . Fresh fecal grab samples collected from 2 pigs per pen (d 21 and 42) were mixed and pooled, and a representative sample was stored in a freezer at $-20^{\circ} \mathrm{C}$ until analyzed. Before chemical analysis, the fecal samples were thawed and dried at $60^{\circ} \mathrm{C}$ for $72 \mathrm{~h}$, after which they were finely ground to pass through a 1-mm screen. All feed and fecal samples were analyzed for $\mathrm{DM}, \mathrm{GE}$, and $\mathrm{N}$ following the procedures outlined by the AOAC (2000). Chromium was analyzed via UV absorption spectrophotometry (Shimadzu UV-1201, Shimadzu, Kyoto, Japan) following the method described by Williams et al. 
(1962).

The digestibility was calculated using the following formula:

$$
\text { Digestibility }(\%)=\left\{1-\left[\left(\mathrm{N}_{\mathrm{f}} \times \mathrm{C}_{\mathrm{d}}\right) /\left(\mathrm{N}_{\mathrm{d}} \times \mathrm{C}_{\mathrm{f}}\right)\right]\right\} \times 100
$$

where $\mathrm{N}_{\mathrm{f}}=$ nutrient concentration in feces $(\% \mathrm{DM}), \mathrm{N}_{\mathrm{d}}=$ nutrient concentration in diet $(\% \mathrm{DM}), \mathrm{C}_{\mathrm{d}}=$ chromium concentration in diet $(\% \mathrm{DM})$, and $\mathrm{C}_{\mathrm{f}}=$ chromium concentration in feces ( $\% \mathrm{DM})$.

For the blood profile analysis, 5 pigs from each treatment were randomly selected and $5-\mathrm{mL}$ blood samples were collected via anterior vena cava puncture on $\mathrm{d} 42$. At the time of collection, blood samples were collected into nonheparinized tubes and vacuum tubes containing $\mathrm{K}_{3}$ EDTA (Becton, Dickinson and Co., Franklin Lakes, NJ, USA) to obtain serum and whole blood, respectively. After collection, serum samples were centrifuged $(3,000 \times \mathrm{g})$ for $15 \mathrm{~min}$ at $4^{\circ} \mathrm{C}$. The white blood cells (WBC), red blood cells (RBC), lymphocyte concentration in the blood were determined using an automatic blood analyzer (ADVIA 120, Bayer, Tarrytown, NY, USA). The blood urea nitrogen (BUN) and creatinine concentrations in the serum were determined using an auto-chemical analyzer (HITACHI 747, Hitachi, Tokyo, Japan). Serum IgG was analyzed using nephelometry (Dade Behring, Marburg, Germany).

Fecal scores were determined at 08:00 and 20:00 h using the following fecal scoring system: 1 hard, dry pellet; 2 firm, formed stool; 3 soft, moist stool that retains shape; 4 soft, unformed stool that assumes shape of container; 5 watery liquid that can be poured. Feces and urine were collected on $\mathrm{d} 14$, and 42 . A total of $300 \mathrm{~g}$ fresh feces samples were stored in $2.6 \mathrm{~L}$ plastic boxes for replicates. The samples were fermented for $7 \mathrm{~d}$ at room temperature $\left(28^{\circ} \mathrm{C}\right)$. After the fermentation period, a Gastec (model GV-100) gas-sampling pump was utilized for gas detection (Gastec Corp., Gastec detector tube No. $3 \mathrm{M}$ and $3 \mathrm{La}$ for $\mathrm{NH}_{3}$; No. 70 and $70 \mathrm{~L}$ for R.SH (total mercaptan), Gastec Corp, detector tube, Japan). The adhesive plasters were punctured, and $100 \mathrm{~mL}$ of headspace air was sampled approximately $2.0 \mathrm{~cm}$ above the feces surface.

\section{Procedures of microbial shedding}

Fecal samples were collected directly via massaging the rectum of 5 pigs in each treatment on d 42. Samples were pooled and immediately placed on ice for transportation to the lab. One gram of the composite fecal sample from each pen was diluted with $9 \mathrm{~mL}$ of $1 \%$ peptone broth (Becton, Dickinson and Co., Franklin Lakes, NJ, USA) and was subsequently homogenized. The bacterial count in fecal samples was conducted by plating a serial 10 -fold dilution (in $1 \%$ peptone solution) into MacConkey agar plates (Difco Laboratories, Detroit, MI, USA) and Lactobacilli medium III agar plates (Medium 638, DSMZ, Braunschweig, Germany) for isolation of E. coli and Lactobacillus, respectively. The Lactobacilli medium III agar plates were then incubated for $48 \mathrm{~h}$ at $39^{\circ} \mathrm{C}$ under anaerobic conditions. The MacConkey agar plates were incubated for $24 \mathrm{~h}$ at $37^{\circ} \mathrm{C}$. The $E$. coli and Lactobacillus colonies were counted immediately after removal from the incubator.

\section{Statistical analysis}

All experimental data were analyzed using the GLM Procedure as a completely randomized design (SAS Inst. Inc., Cary, NC, USA). The pen was used as the experimental unit. Differences among treatment means were determined using t-test. A probability level of $\mathrm{p} \leq 0.05$ was used as the criterion for statistical significance.

\section{RESULTS}

\section{Piglet performance}

Body weight, ADG, ADFI, and $\mathrm{G} / \mathrm{F}$ are shown in Table 2. The initial $\mathrm{BW}$ was similar between treatments at $6.42 \pm 0.12 \mathrm{~kg}$ (mean \pm standard error). At $\mathrm{d} 7$ and 21 , no differences in BW were observed. However, final BW (d 42) was increased $(p<0.05)$ in piglets fed the PROT diet more than those fed the CON diet. The ADG from d 1 to 7 and $d 1$

Table 2. Performance of weanling pigs fed diets supplemented with and without protease enzyme

\begin{tabular}{|c|c|c|c|c|}
\hline Item & $\mathrm{CON}^{1}$ & PROT $^{1}$ & $\mathrm{SEM}^{2}$ & p-value ${ }^{3}$ \\
\hline \multicolumn{5}{|l|}{ BW (kg) } \\
\hline d 1 & 6.42 & 6.42 & 0.12 & 0.9889 \\
\hline d 7 & 8.35 & 8.61 & 0.16 & 0.2510 \\
\hline d 21 & 14.52 & 15.17 & 0.25 & 0.0758 \\
\hline $\mathrm{d} 42$ & 25.75 & 27.04 & 0.38 & 0.0213 \\
\hline \multicolumn{5}{|l|}{$\mathrm{ADG}(\mathrm{g} / \mathrm{d})$} \\
\hline d 1 to 7 & 277 & 313 & 8.7 & 0.0068 \\
\hline d 8 to 21 & 441 & 469 & 12 & 0.1023 \\
\hline d 22 to 42 & 535 & 565 & 11.3 & 0.0898 \\
\hline d 1 to 42 & 460 & 491 & 7.4 & 0.0052 \\
\hline \multicolumn{5}{|l|}{ ADFI (g/d) } \\
\hline d 1 to 7 & 326 & 358 & 5.1 & 0.0002 \\
\hline d 8 to 21 & 596 & 626 & 5.3 & 0.0004 \\
\hline d 22 to 42 & 855 & 866 & 6.6 & 0.0865 \\
\hline d 1 to 42 & 678 & 701 & 9.2 & 0.0907 \\
\hline \multicolumn{5}{|l|}{$\mathrm{G} / \mathrm{F}$} \\
\hline $\mathrm{d} 1$ to 7 & 0.850 & 0.874 & 0.020 & 0.3554 \\
\hline d 8 to 21 & 0.740 & 0.749 & 0.019 & 0.7380 \\
\hline d 22 to 42 & 0.626 & 0.652 & 0.011 & 0.1509 \\
\hline d 1 to 42 & 0.678 & 0.700 & 0.009 & 0.1140 \\
\hline
\end{tabular}

SEM, standard error of the mean; BW, body weight; ADG, average daily gain; ADFI, average daily feed intake; $\mathrm{G} / \mathrm{F}$, gain per feed.

${ }^{1} \mathrm{CON}$, control diet; PROT, protease diet $(0.02 \%$ of the diet).

${ }^{2} \mathrm{n}=25 /$ treatment.

${ }^{3}$ p-value for the effect of diet. 
to 42 , and ADFI from $\mathrm{d} 1$ to 7 and $\mathrm{d} 8$ to 21 were increased significantly in piglets fed the PROT diet compared to those fed the CON diet. However, the G/F in the CON and PROT group was similar throughout the study.

\section{Apparent total tract digestibility}

The ATTD of DM, N, and GE at d 21 and 42 are shown in Table 3. The ATTD of DM and N were increased $(p<0.05)$ in pigs fed the PROT diet at $\mathrm{d} 21$ and 42 compared with pigs fed the CON diet. However, no effect was observed on the ATTD of GE at d 21 and d 42 .

\section{Blood profile measurements}

There were no differences in concentrations of RBC, WBC, lymphocyte, BUN, and IgG between treatment groups (Table 4). However, the creatinine concentration in blood was decreased $(p<0.05)$ in piglets belonging to the PROT group compared to the CON group.

\section{Fecal score, fecal gas emission, and fecal microflora}

There was no difference in fecal score between treatments (Table 5). The $\mathrm{NH}_{3}$ emission from the feces was reduced $(\mathrm{p}<0.05)$ in piglets fed the PROT diet relative to those fed the CON diet. However, R.SH emission (total mercaptan) was the same in both groups. Fecal Lactobacillus and $E$. coli populations were not affected by protease enzyme supplementation.

\section{DISCUSSION}

The supplementation of diets with exogenous protease enzyme to improve protein utilization has generated interest within the modern pig industry. However, in relation to their application in poultry nutrition, the use of protease in swine diets has not been explored as extensively. This is because overall, pigs have greater capacity to digest dietary proteins than chickens due to their better gut fermentative capacity and longer digesta transit time. However, in early-weaned

Table 3. Nutrient digestibility in weanling pigs fed diets supplemented with and without protease enzyme

\begin{tabular}{lllll}
\hline Item & $\mathrm{CON}^{1}$ & PROT $^{1}$ & SEM $^{2}$ & p-value \\
\hline 3 week (\%) & & & & \\
$\quad$ Dry matter & 82.65 & 86.03 & 0.86 & 0.0266 \\
$\quad$ Nitrogen & 81.34 & 85.30 & 0.90 & 0.0155 \\
$\quad$ Energy & 83.04 & 83.70 & 0.74 & 0.5951 \\
6 week (\%) & & & & \\
$\quad$ Dry matter & 81.21 & 84.66 & 0.89 & 0.0245 \\
$\quad$ Nitrogen & 80.47 & 84.02 & 0.87 & 0.0229 \\
Energy & 82.81 & 83.04 & 0.74 & 0.8462 \\
\hline
\end{tabular}

SEM, standard error of the mean.

${ }^{1} \mathrm{CON}$, control diet; PROT, protease diet $(0.02 \%$ of the diet $)$.

${ }^{2} n=6 /$ treatment.

${ }^{3} \mathrm{p}$-value for the effect of diet.
Table 4. Blood profiles of weanling pigs fed diets supplemented with and without protease enzyme

\begin{tabular}{lcccc}
\hline Item & CON $^{1}$ & PROT $^{1}$ & SEM $^{2}$ & p-value $^{3}$ \\
\hline RBC $\left(10^{6} / \mu \mathrm{L}\right)$ & 5.68 & 6.44 & 0.73 & 0.5861 \\
WBC $\left(10^{3} / \mu \mathrm{L}\right)$ & 17.4 & 15.87 & 2.08 & 0.6274 \\
Lymphocyte $(\%)$ & 6.95 & 10.33 & 3.18 & 0.5149 \\
Creatinine $(\mathrm{mg} / \mathrm{dL})$ & 1.14 & 0.81 & 0.04 & 0.0013 \\
BUN $(\mathrm{mg} / \mathrm{dL})$ & 7.83 & 7.88 & 0.79 & 0.9658 \\
IgG $(\mathrm{mg} / \mathrm{dL})$ & 475.8 & 490.3 & 27.5 & 0.7402 \\
\hline
\end{tabular}

SEM, standard error of the mean; RBC, red blood cells; WBC, white blood cells; BUN, blood urea nitrogen; IgG, immunoglobulin G.

${ }^{1} \mathrm{CON}$, control diet; PROT, protease diet $(0.02 \%$ of the diet).

${ }^{2} \mathrm{n}=4$ /treatment.

${ }^{3} \mathrm{p}$-value for the effect of diet.

piglets, the stress of weaning adversely affects the digestion of feed nutrients including proteins and amino acids (Pluske et al., 1997; Hedemann and Jensen, 2004). Therefore, it is worth investigating to determine the effects of exogenous protease supplementation in weanling pigs.

In the current study, PROT diet increased the final BW and the overall ADG of newly weaned piglets but did not affect the overall G/F. Previous study conducted by Wang et al. (2011) reported an increase in ADG when nursery pigs were fed diet supplemented with a protease enzyme (keratinase). Similarly, the growth performance of weanling pigs was improved when protease enzyme was added in a piglet diet based on low digestible protein sources (Zuo et al., 2015). Improvements in the utilization of dietary proteins and amino acids were anticipated with protease supplementation and may have accounted for the observed improvements in growth performance. Indeed, DM and $\mathrm{N}$ digestibility were increased significantly in weanling pigs fed with PROT diets. The ATTD of DM and N components of the PROT diets were increased consistently relative to the control when measured at d 21 and d 42. Guggenbuhl et al. (2012) and Zuo et al. (2015) also reported an increased in crude protein digestibility in a corn-soy based diet

Table 5. Fecal microflora, fecal score, and fecal gas emission in weanling pigs fed diets supplemented with and without protease enzyme

\begin{tabular}{lcccc}
\hline Item & CON $^{1}$ & PROT $^{1}$ & SEM $^{2}$ & p-value $^{3}$ \\
\hline R.SH $(\mathrm{ppm})$ & 2.2 & 1.8 & 0.2 & 0.1097 \\
$\mathrm{NH}_{3}(\mathrm{ppm})$ & 2.0 & 1.2 & 0.1 & 0.0039 \\
Lactobacillus $\left(\log _{10} \mathrm{cfu} / \mathrm{g}\right)$ & 7.38 & 7.54 & 0.08 & 0.2218 \\
E. coli $\left(\log _{10} \mathrm{cfu} / \mathrm{g}\right)$ & 6.22 & 6.14 & 0.04 & 0.1852 \\
Fecal score & 3.62 & 3.60 & 0.01 & 0.8976 \\
\hline
\end{tabular}

SEM, standard error of the mean.

${ }^{1} \mathrm{CON}$, control diet; PROT, protease diet $(0.02 \%$ of the diet).

${ }^{2} \mathrm{n}=5 /$ treatment.

${ }^{3}$ p-value for the effect of diet.

${ }^{4}$ Fecal score: $1=$ hard, dry pellet, $2=$ firm, formed stool, $3=$ soft, moist stool that retains shape, $4=$ soft, unformed stool that assumes shape of container, $5=$ watery liquid that can be poured. 
supplemented with a protease when fed to weanling pigs. Huo et al. (1993) explained that protease enzyme may neutralize anti-nutritive factors such as protease inhibitors and thus could account for its positive effect on protein digestibility. An in vitro study utilizing gel electrophoresis demonstrated the degradation of purified lectin, Kunitz and Bowman Birk inhibitors after being incubated in a solution with a protease enzyme (Nielsen et al., 2013). In terms of energy digestibility, PROT diet did not impact the ATTD of $\mathrm{GE}$ in the current study. This is in contrast with the findings of McAllister (1993) who reported an increase in the digestion of cornstarch following the application of a serine protease in a rumen in vitro model. In this study, the improvement in GE digestibility was attributed to the disruption of the protein matrix surrounding the starch granules. In parallel, energy digestibility values of proteasesupplemented feed ingredients selected to represent both vegetable (soybean meal, rapeseed meal, and peas) and animal proteins (meat and bone meal) were increased significantly in adult cockerels when compared to the unsupplemented group (Gauthier, unpublished data).

In the current study, blood creatinine concentration was decreased significantly in nursery pigs fed PROT diet but RBC, WBC, lymphocyte, IgG, and BUN levels were similar to the CON group. The degradation of creatine and creatine phosphate in muscle is the main source of creatinine fluxed in the blood. Creatinine levels in the blood can be elevated during periods of diarrhea as a result of the increase mobilization of protein reservoirs from muscle to compensate for the decreased nutrient intake and/or absorption. However, because the piglets from the current study did not suffer from diarrhea (as indicated by fecal score), the lower creatinine levels in the PROT supplemented diet may indicate an overall better amino acid status relative to the CON pigs. Brosnan et al. (2011) reported that the replacement of degraded creatine in the muscle imposes an appreciable burden on the metabolism of methionine and arginine, and thus, negatively impacting the total body amino acid balance.

The high protein levels in weaning diets coupled with the impaired ability of the weanling pigs to digest dietary proteins as a result of weaning may result in the proliferation of pathogenic bacteria in the gut and subsequently increased predisposition to diarrhea (Porter and Kentworthy, 1969; Dong et al., 1996). Therefore, it was hypothesized that feeding weanling pigs with protease enzyme would reduce enteric pathogens and lower the incidence of diarrhea. However, in the current study, the PROT diet did not affect the fecal microflora (Lactobacillus and E. coli) and fecal score of weanling pigs. The observed fecal score was also not indicative of any incidence of diarrhea for both groups. In contrast, Zhang et al. (2014) found that dietary supplementation of an exogenous multi-enzyme consisting of xylanase, amylase, and protease, increased the counts of Lactobacilli spp. and reduced the populations of Escherichia coli spp. in the feces, resulting in reduced diarrhea index in weanling piglets. The reason for the differences in between experiments could have been due to the differences in types and levels of enzymes used, the nature of the diets (Mirzaie et al., 2012; Wen et al., 2012) and the sanitary condition of the facility where the study was conducted. In the current study, the piglets were housed in a relatively clean research facility. It is well recognized that the level of bacterial population in the gastrointestinal tract can be dictated by sanitary conditions in the environment where pigs are raised.

The emission of odorous gas such as $\mathrm{NH}_{3}$ from pig production facilities contributes to pollution in the environment and may affect the performance of pigs. In the current study, the fecal $\mathrm{NH}_{3}$ concentration was significantly decreased by PROT diet. On the contrary, McAlpine et al. (2012) reported that finisher pigs offered proteasesupplemented diets alone had significantly higher $\mathrm{NH}_{3}$ emissions compared to basal fed pigs. However, $\mathrm{NH}_{3}$ emissions were reduced when protease was combined with xylanase. Although the large differences in age and diet might have accounted for the observed differences in results across experiments, further research is necessary to elucidate the important factors involved. Microbial fermentation of undigested proteins and amino acids in the hindgut produces $\mathrm{NH}_{3}$ and contributes to the $\mathrm{NH}_{3}$ output in the manure (Gaskins, 2000). Therefore, in the current study, the lower fecal $\mathrm{NH}_{3}$ concentration in the PROT pigs may indicate better digestion of dietary proteins and amino acids. This is through limiting the availability of non-digested proteins, which then serve as substrate for $\mathrm{NH}_{3}$ production in the large intestine.

Overall, it can be concluded that protease supplementation in weanling pigs can effectively improved growth performance and nutrient digestibility, particularly of dietary proteins. Furthermore, protease supplementation can significantly reduce fecal $\mathrm{NH}_{3}$ emission, thus, potentially serving as a tool in lowering noxious gas contribution of livestock production in the environment.

\section{CONFLICT OF INTEREST}

We certify that there is no conflict of interest with any financial organization regarding the material discussed in the manuscript.

\section{REFERENCES}

Adebiyi, A. O. and O. A. Olukosi. 2015. Metabolizable energy content of wheat distillers' dried grains with solubles supplemented with or without a mixture of carbohydrases and protease for broilers and turkeys. Poult. Sci. 94:1270-1276. 
AOAC. 2000. Official Methods of Analysis. 17th ed. Assoc. Off. Anal. Chem. Washington, DC, USA.

Boudry, G., V. Péron, I. ILe Huërou-Luron, J. P. Lallès, and B. Sève. 2004. Weaning induces both transient and long-lasting modifications of absorptive, secretory, and barrier properties of piglet intestine. J. Nutr. 134:2256-2262.

Brosnan, J. T., R. P. da Silva, and M. E. Brosnan. 2011. The metabolic burden of creatine synthesis. A Review. Amino Acids 40:1325-1331.

Dong, G., A. Zhou, F. Yang, K. Chen, K. Wang, and D. Dao. 1996. Effect of dietary protein levels on the bacterial breakdown of protein in the large intestine, and diarrhoea in early-weaned piglets. Acta Vet. Zootec. Sin. 27:293-302.

Gaskins, H. R. 2000. Intestinal bacteria and their influence on swine growth. In Swine Nutrition (Eds. A. J. Lewis and L. L. Southern). 2nd ed. CRC Press, New York, NY, USA. pp. 585608.

Guggenbuhl, P., Y. Waché, and J. W. Wilson. 2012. Effects of dietary supplementation with a protease on the apparent ileal digestibility of the weaned piglet. J. Anim. Sci. 90:152-154.

Hedemann, M. S. and B. B. Jensen. 2004. Variations in enzyme activity in stomach and pancreatic tissue and digesta in piglets around weaning. Arch. Anim. Nutr. 58:47-59.

Htoo, J. K., B. A. Araiza, W. C. Sauer, M. Rademacher, Y. Zhang, M. Cervantes, and R. T. Zijlstra. 2007. Effect of dietary protein content on ileal amino acid digestibility, growth performance, and formation of microbial metabolites in ileal and cecal digesta of early-weaned pigs. J. Anim. Sci. 85:3303-3312.

Huo, G. C., V. R. Fowler, and M. Bedford. 1993. The use of enzymes to denature antinutritive factors in soybean. In: Recent Advances of Research in Antinutritional Factors in Legume Seeds (Eds. A. F. B. van der Poel, J. Huisman, and H. S. Saini). Proceedings of the Second International Workshop on 'Antinutritional factors (ANFs) in Legume seeds'. Wageningen Pers, Wageningen, The Netherlands. pp. 517-521.

Kong, C. and O. Adeola. 2014. Evaluation of amino acid and energy utilization in feedstuff for swine and poultry diets. Asian Australas. J. Anim. Sci. 27:917-925.

McAllister, T. A., R. C. Phillippe, L. M. Rode, and K. J. Cheng. 1993. Effect of the protein matrix on the digestion of cereal grains by ruminal microorganisms. J. Anim. Sci. 71:205-212.

McAlpine, P. O., C. J. O'Shea, P. F. Varley, P. Solan, T. Curran, and J. V. O'Doherty. 2012. The effect of protease and nonstarch polysaccharide enzymes on manure odor and ammonia emissions from finisher pigs. J. Anim. Sci. 90:369-371.
Mirzaie, S., M. Zaghari, S. Aminzadeh, M. Shivazad, and G. G. Mateos. 2012. Effects of wheat inclusion and xylanase supplementation of the diet on productive performance, nutrient retention, and endogenous intestinal enzyme activity of laying hens. Poult. Sci. 91:413-425.

Nielsen, P., K. Pontoppidan, M. U. Faruk, J. Broz, and I. Knap. 2013. In vitro degradation of soybean anti-nutritional factors by a mono component protease. Int. Poult. Sci. Forum. M80. (Abstr.).

NRC. 2012. Nutrient Requirements of Swine. 11th Rev. Ed. National Academies Press, Washington, DC, USA.

Opoku, E. Y., H. L. Classen, and T. A. Scott. 2015. Evaluation of inclusion level of wheat distillers dried grains with solubles with and without protease or $\beta$-mannanase on performance and water intake of turkey hens. Poult. Sci. 94:1600-1610.

Pluske, J. R., D. J. Hampson, and I. H. Williams. 1997. Factors influencing the structure and function of the small intestine in the weaned pig: A Review. Livest. Prod. Sci. 51:215-236.

Porter, P. and R. Kentworthy. 1969. A study of intestinal and urinary amines in pigs in relation to weaning. Res. Vet. Sci. 10:440-447.

Wang, D., X. S. Piao, Z. K. Zeng, T. Lu, Q. Zhang, P. F. Li, L. F. Xue, and S. W. Kim. 2011. Effects of keratinase on performance, nutrient utilization, intestinal morphology, intestinal ecology and inflammatory response of weaned piglets fed diets with different levels of crude protein. Asian Australas. J. Anim. Sci. 24:1718-1728.

Wen, C., L. C. Wang, Y. M. Zhou, Z. Y. Jiang, and T. Wang. 2012. Effect of enzyme preparation on egg production, nutrient retention, digestive enzyme activities, and pancreatic enzyme messenger RNA expression of late-phase laying hens. Anim. Feed Sci. Technol. 172:180-186.

Williams, C. H., D. J. David, and O. Iismaa. 1962. The determination of chromic oxide in faeces samples by atomic absorption spectrophotometry. J. Agric. Sci. 59:381-385.

Yu, B., S. T. Wu, C. C. Liu, R. Gauthier, and P. W. S. Chiou. 2006. Effects of enzyme inclusion in a maize-soybean diet on broiler performance. Anim. Feed Sci. Technol. 134:283-294.

Zhang, G. G., Z. B. Yang, Y. Wang, W. R. Yang, and H. J. Zhou. 2014. Effects of dietary supplementation of multi- enzyme on growth performance, nutrient digestibility, small intestinal digestive enzyme activities, and large intestinal selected microbiota in weanling pigs. J. Anim. Sci. 92:2063-2069.

Zuo, J., B. Ling, L. Long, T. Li, L. Lahaye, C. Yang, and D. Feng. 2015. Effect of dietary supplementation with protease on growth performance, nutrient digestibility, intestinal morphology, digestive enzymes and gene expression of weaned piglets. Anim. Nutr. 1:276-282. 